\title{
Cerebellar Precursors Transplanted to the Neonatal Dentate Gyrus Express Features Characteristic of Hippocampal Neurons
}

\author{
Carlos Vicario-Abejón, ${ }^{1, a, *}$ Miles G. Cunningham,,$^{3, *}$ and Ronald D. G. McKay ${ }^{1,2}$ \\ Departments of 'Brain and Cognitive Sciences and 'Biology, Massachusetts Institute of Technology, Cambridge, \\ Massachusetts 02139, and ${ }^{3}$ Harvard Medical School, Boston, Massachusetts 02115
}

\begin{abstract}
During the development of the CNS, a salient issue is whether neuronal phenotype is defined by the lineage or by the environment of precursor cells. Transplants permit these two possibilities to be tested, as cell fate can be examined in a new location. Dissociated cerebellar cells from newborn rats treated with tritiated thymidine or from NSElac $Z$ transgenic mice were grafted into the dentate gyrus of the developing hippocampus. Implanted cells integrated into the granule cell layer, which contains the cell bodies of host granule neurons. Immunohistochemistry showed that grafted cells in the granule cell layer, like the host hippocampal granule neurons, were calbindin positive and upregulated FOS in a seizure paradigm. Electron microscopic analysis also showed that cells grafted to the dentate gyrus share features with host dentate neurons. These assays indicate that transplanted cerebellar cells acquired morphological and antigenic features characteristic of hippocampal neurons. These results show that metencephalic precursors are capable of differentiating in response to signals in the telencephalon, suggesting that the environment controls the regional fate of neuronal precursor cells during neurogenesis.
\end{abstract}

[Key words: cerebellum, hippocampus, granule neuron, cell tate, transplantation, NSE-LacZ]

Cell lineage studies show that many neural progenitors are multipotent (Turner and Cepko, 1987; Gray et al., 1988; Holt et al., 1988; Wetts and Fraser, 1988). The developmental capacities of these cells appear to become progressively restricted, suggesting that extracellular and intrinsic factors may have interrelated roles during neuronal differentiation (Luskin et al., 1993; Mione et al., 1994; reviewed in McConnell, 1991). In situ hybridization

\footnotetext{
Received March 2, 1995; revised June 9, 1995; accepted June 14, 1995.

* C.V.-A. and M.G.C. contributed equally to this work. For the gift of NSElacZ transgenic mice, we thank Dr. J. G. Sutcliffe (Research Institute of Scripps Clinic, La Jolla, CA). Special thanks to G. Vaughn for helping in the Cibachrome processing. We are grateful to Dr. R. Moratalla for suggestions on immunohistochemistry. We also thank R. Josephson, Dr. T. Hayes, and all of the members of our group for their suggestions and critical comments of the manuscript. This work was supported by the Pew Charitable Trust, the Rita Allen Foundation, and the NIH (R.D.G.M.). C.V.-A. was supported by PFPI (Spanish Ministry of Education) and M.G.C. by a MSTP grant (Harvard Medical School).

Correspondence should be addressed to Ronald McKay, Laboratory of Molecular Biology, National Institute of Neurological Disorders and Stroke, National Institutes of Health, Building 36/Room 3DO2, 36 Convent Drive, MSC 4092, Bethesda, MD 20892-4092.

aPresent address: Laboratory of Molecular Biology, National Institute of Neurological Disorders and Stroke, National Institutes of Health, Bethesda, MD 20892-4092.

Copyright (C) 1995 Society for Neuroscience $0270-6474 / 95 / 156351-13 \$ 05.00 / 0$
}

shows that homeotic, pax, and wnt genes are expressed in a complex pattern in specific regions of the developing brain (Gruss and Walther, 1992; Simeone et al., 1992; Krumlauf, 1993). These results and knock-out data suggest that these genes are involved in the regional specification of the CNS (McMahon and Bradley, 1990; Rubenstein et al., 1994). Transplantation exposes cells to a new environment and allows analysis of the role of cell-autonomous mechanisms and cell-cell interactions in defining the patterns of gene expression and fate choices in neuronal precursor cells. Consistent with lineage data, transplantation provides evidence for a developmentally equivalent precursor cell in the cortex (McConnell, 1988; Barbe and Levitt, 1991; McConnell and Kaznowski, 1991). Similar conclusions have been derived from manipulations of the spinal cord (Yamada et al., 1991). However, these studies do not establish whether neuronal progenitor cells can respond appropriately to differentiation signals in an ectopic brain area.

Transplantation of intact tissue between brain regions suggests that the regional specification of the CNS is determined in the late gastrula and early neurula before neuronal differentiation has begun (Jacobson, 1964; Alvarado-Mallart and Sotelo, 1982; Kromer et al., 1983; Guthrie et al., 1992). Interestingly, recent results from transplantation of tissue pieces suggest that the cells of the neuroepithelium may not be committed to a specific regional fate (Alvarado-Mallart et al., 1990; Nakamura, 1990; Martínez et al., 1991). These results challenge the previously accepted view of regional commitment and indicate that neuronal precursor cells may be respecified. They imply that regional differences in the brain may not be the result of a cell autonomous program established early in development; rather these differences may be maintained by a series of cell-cell interactions that continue throughout neurogenesis.

Iransplantation of dissociated cells from one developing brain region into another provides a direct test of the commitment of individual cells to specific fates. Immortalized and primary CNS precursor cells have been shown to differentiate into regionspecific neurons when transplanted to ectopic sites (Renfranz et al., 1991; Fishell, 1995). Immortalized precursor cells derived from the cerebellar external granule layer (EGL) give rise to different types of neuronal and glial cells upon transplantation into the cerebellum (Snyder et al., 1992; Gao and Hatten, 1994). However, homotopic grafts of mes/metencephalic vesicles and primary EGL precursors reveal that the granule neurons are the only cerebellar cells derived from the EGL suggesting that the EGL precursors are commited to a specific neuronal fate (Hallonet et al., 1990; Hallonet and Le Douarin, 1993; Gao and Hatten, 1994). Since heterotopic transplantation exposes the 

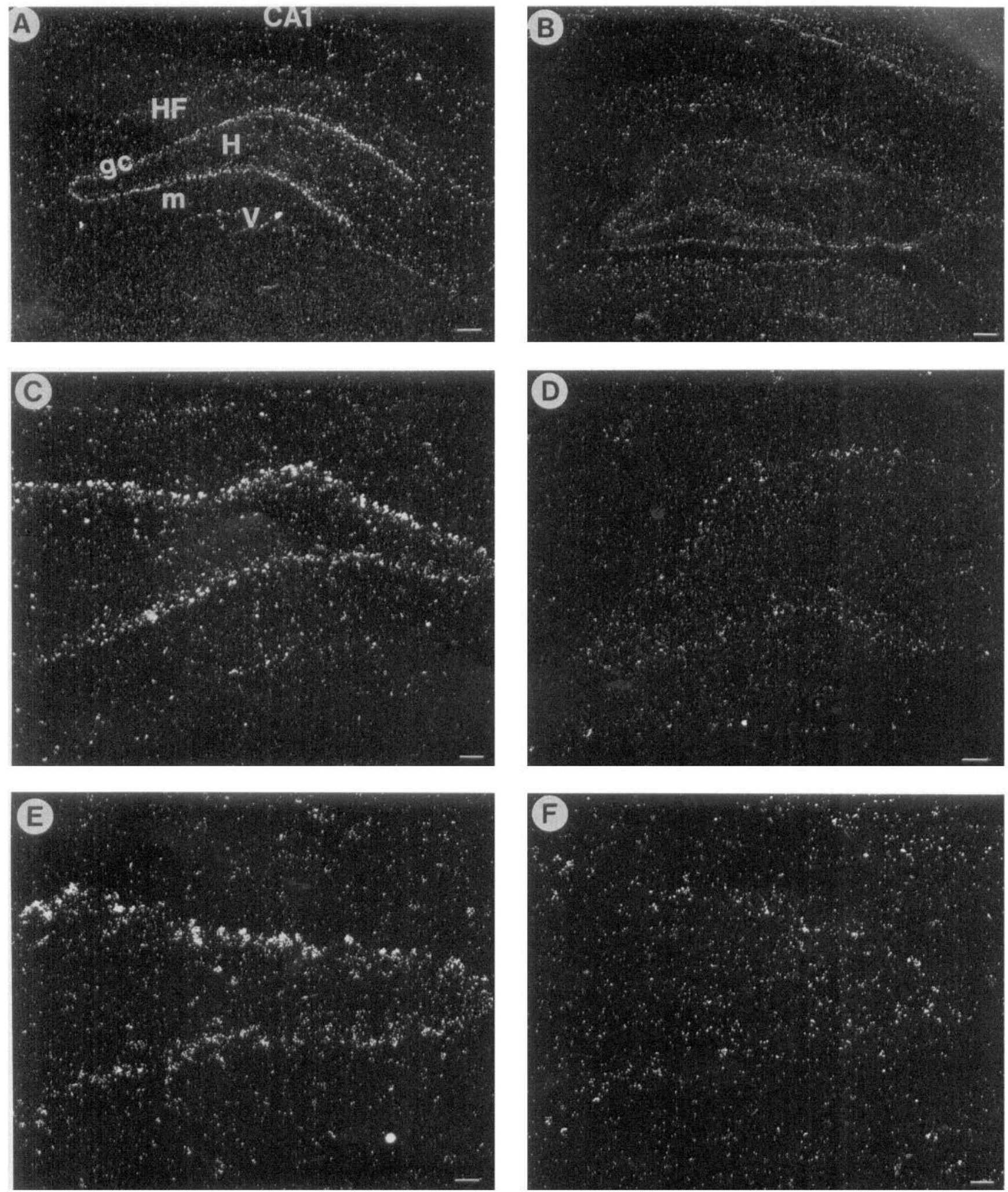

Figure 1. ${ }^{3} \mathrm{H}$-Thymidine-labeled cerebellar cells grafted into the dentate gyrus are found predominantly in the granule cell layer. Living ( $A$, $C$, and $E$ ) or dead $(B, D$, and $F) .{ }^{3} \mathrm{H}$-Thymidine-labeled cerebellar cells were transplanted into the hilar region $(H$; see $A)$ of the dentate gyrus of postnatal day 2 rats and visualized as silver grains by using autoradiography. $A$ illustrates the hippocampal subregions of an implanted animal viewed under dark-field illumination at $50 \times$ magnification. When living cerebellar cells were transplanted (see $A, C$, and $E$ ) clusters of silver grains concentrate predominantly in the granule cell layer $(\mathrm{gc})$. Fewer clusters of grains are found in the molecular layer $(m)$. The number of silver grains found in the CA1-CA3 region of the pyramidal layer was similar to the background level. Silver grains are also found in the hippocampal fissure $(H F)$ and in the third and lateral ventricles $(V)$. Animals transplanted with dead cells show low levels of silver grains in all of the subregions of the hippocampal formation $(B, D$, and $F)$. Photographic magnification: $A$ and $B, 50 \times ; C$ and $D, 100 \times ; E$ and $F, 200 \times$. Section thickness: $20 \mu \mathrm{m}$. Scale bars: $A$ and $B, 100 \mu \mathrm{m} ; C$ and $D, 50 \mu \mathrm{m} ; E$ and $F, 25 \mu \mathrm{m}$. These results were consistent in all transplanted animals with optimal placement of the graft. 

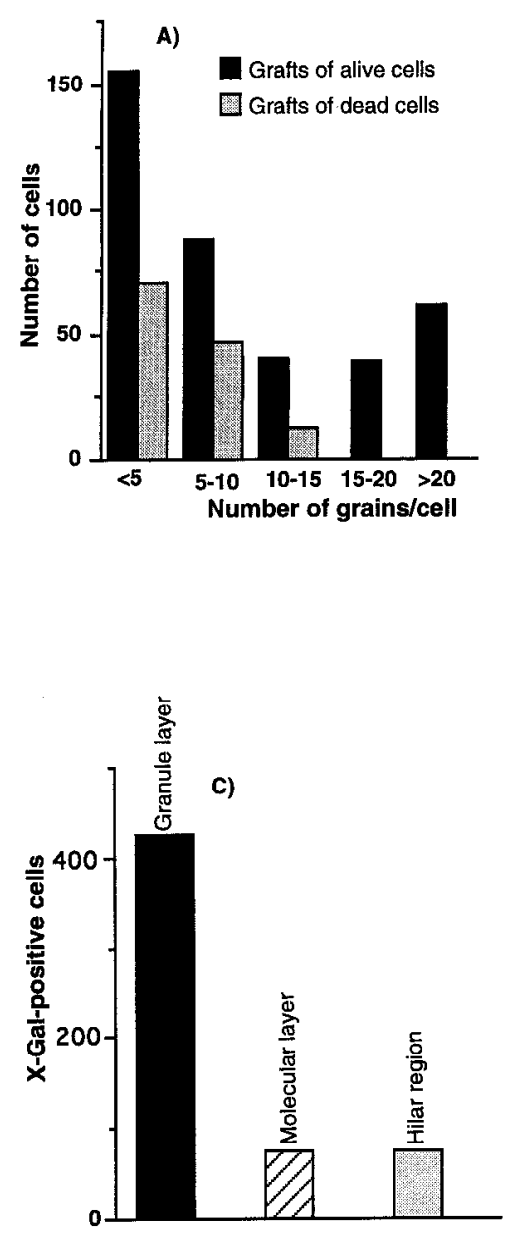

cells to signals different from the donor site, we performed transplants of dissociated cells derived from the early postnatal cerebellum into the developing dentate gyrus. Our results show that cerebellar precursors acquire features characteristic of hippocampal dentate neurons and suggest that local signals acting during neurogenesis direct neuronal precursors to region-specific fates.

\section{Materials and Methods}

Materials. Materials were purchased from the following sources: Dulbecco's modified Eagle's Medium (DMEM), fetal calf serum, (FCS), trypan blue, paraformaldehyde, poly-L-lisine, kainic acid, cresyl violet, 3,3' diaminobenzidine (DAB), (3-[4,5-dimethylthiazol-2-yl]-2,5-diphenyltetrazolium bromide) (MTT), and monoclonal antibody anti-calbindinD28kd from Sigma (St. Louis, MO); thymidine-[methyl- $\left.{ }^{3} \mathrm{H}\right]$, $\left({ }^{3} \mathrm{H}-\right.$ thymidine), from New England Nuclear (Boston, MA); emulsion NTB2, developer D19, and rapid fixer from Eastman Kodak (New Haven, CT); trypsin and deoxyribonucleasel (DNaseI) from Worthington (Treehold, $\mathrm{NJ}) ; 5$-Br-4-Cl-3-indolyl $\beta$-galactoside (X-Gal) from GIBCO BRL (Grand Island, NY); Vectastain ABC kit from Vector Laboratories (Burlingame, CA); Red fluorescent latex microspheres (red beads) from Lumafluor, (New City, NJ); Permount from Fisher Scientific (Fair Lawn, $\mathrm{NJ})$; OCT from Miles (Elkhart, IN); polyclonal antibodies anti-neuron specific enolase (anti-NSE) from Polysciences, (Warringtown, PA), and anti-FOS proteins from Cambridge Res. Biochem. (Cambridge, MA); monoclonal antibody against glial fibrillary acidic protein (anti-GFAP) from ICN Biomedicals, (Costa Mesa, CA); polyclonal antibody against $E$. coli $\beta$-galactosidase from 5 Prime-3 Prime (Boulder, $\mathrm{CO}$ ).

Animals. Rats were purchased from Taconic (Germantown, NY), C57Bl6 and SJL mice from Jackson Laboratory (Bar Harbor, ME), and
Figure 2. Numbers of grafted cells in the dentate gyrus and its subregions. $A$, Numbers of cells with corresponding quantities of overlying silver grains, for representative sections, after implantation of living or dead ${ }^{3} \mathrm{H}$-thymidine-labeled cerebellar cells. Cells possessing $>20$ grains were counted as positive. Twenty or more grains overlying a cells nucleus was considered safely beyond the limits of nonspecific background signal, and these cells were scored as cerebellum derived. $B$, Numbers of positively scored cells located in the dentate gyrus subregions from two serially sectioned animals. $C$, Numbers of $X$-Gal-posilive cells located in the dentate gyrus subregions from one optimal animal.
NSE-lac'Z transgenic mice were a gift from J. G. Sutcliffe's laboratory (Research Institute of Scripps Clinic, La Jolla, CA). Neuroepithelial cell suspensions were prepared from postnatal 2-d-old (P-2) Sprague-Dawley rat pups, and P-2 F1 hybrid (C57B16 $\times$ SJL) transgenic mice carrying a 1.8 kilobase $(\mathrm{kb})$ rat NSE promoter fragment fused to an $E$. coli lac $Z$ gene (Forss-Petter et al., 1990). Before the dissection, the rat pups were injected intraperitoneally every $6 \mathrm{hr}$ for $24 \mathrm{hr}$ with thymidine[methyl ${ }^{3} \mathrm{H}$ ] at a dose of $15 \mu \mathrm{Ci} / \mathrm{g}$. In the early postnatal cerebellum, this procedure mainly labels precursors for granule ncurons (Mialc and Sidman, 1961; Altman and Das, 1965) (see Discussion). The implants were placed in P-2 Sprague-Dawley rats and in P-4 C57B16 $\times$ SJL mice.

Forty-two newborns received transplants of P-2 cerebellar cells to the right dentate gyrus: 14 rats received tritiated thymidine-labeled allografts, 18 rats received transgenic xenografts, and 10 mice received transgenic allografts. Eleven newborns received transplants of P-2 cerebellum to the right cerebellar hemisphere: 5 rats received tritiated thymidine-labeled allografts, and 6 rats received transgenic xenografts. To control for the specificity of radiolabeling, five rats received sham implants of radiolabeled primary cerebellar cells that had been freeze-thaw killed prior to grafting. To assay for lesion-induced, nonspecific, or endogenous $\beta$-galactosidase activity, nine rats received nontransgenic grafts into the dentate gyrus $(n-5)$ or the cerebellum $(n-4)$. Thus, a total of 67 transplanted animals were used in this study. An additional seven animals were eliminated from the study due to poor survival or suboptimal graft placement.

Preparation of cerebellar cell suspensions. Newborn animals were deeply anesthetized hypothermically. Their cerebella were removed, placed in calcium and magnesium-free Hanks' balanced salt solution (CMF-HBSS) at $4^{\circ} \mathrm{C}$, and cleaned of meninges and blood vessels using a dissecting microscope. The cerebella were then placed in CMF-HBSS containing $0.01 \%$ DNAseI (1700-3300 U/mg) and chopped into small 


\section{A. X-Gal-posittive cells}

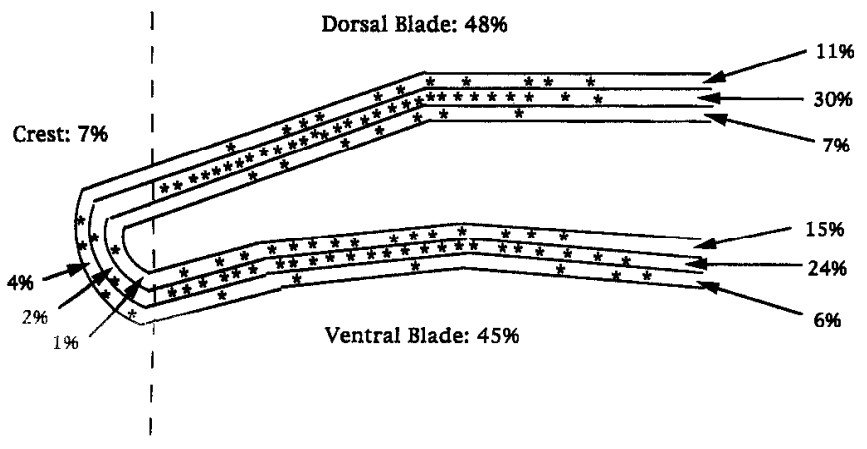

\section{B. 3H-Thymidine-positive cells}

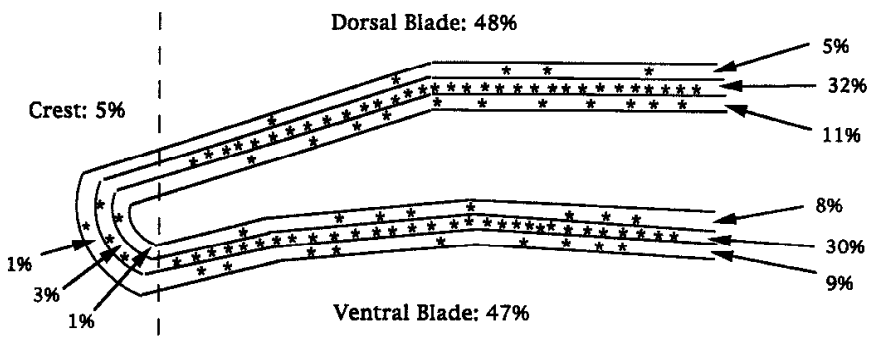

Figure 3. Distribution of X-Gal-positive cells and ${ }^{3} \mathrm{H}$-thymidine-poscells located in the dentate gyrus granule cell layer. The dorsal and ventral blades and the crest of the granule cell layer were divided into three shells according to previous studies (Schlessinger et al., 1975; Altman and Baycr, 1990): an outer, an inner, and an intermediate shell. This was done in order to illustrate the organization of the transplanted cells as it relates with the gradient of formation of the dentate gyrus (see above references). The percentages of cells found in each shell of the granule cell layer from representative animals are given. Note that $56-65 \%$ of the cerebellar transplanted cells are located in the intermediate shell.

pieces. The tissue was incubated in the presence of $0.025 \%$ trypsin (200-300 U/mg) and $0.1 \%$ DNAseI for $5 \mathrm{~min}$ at $37^{\circ} \mathrm{C}$, and the trypsin activity was inhibited by addition of DMEM $+10 \%$ FCS. After centrifugation at $1000 \mathrm{rpm}$ for $5 \mathrm{~min}$ at $4^{\circ} \mathrm{C}$, the tissue was triturated in CMF-HBSS containing 1\% DNAseI by using a P-1000 followed by a P-200 Pipetman pipette. The resulting cell suspension was centrifuged at $2000 \mathrm{rpm}$ for $5 \mathrm{~min}$ at $4^{\circ} \mathrm{C}$, and the cell pellet resuspended in $\mathrm{CMF}$ HBSS. The cells were counted and the viability was consistently between $85 \%$ and $93 \%$ using the trypan blue dye exclusion method. The final volume of the cell suspension was adjusted to obtain a cell density of 100,000 viable cells $/ \mu \mathrm{l}$. Red beads at a concentration of $5 \%(\mathrm{v} / \mathrm{v})$ were added in order to follow the graft after transplantation. A $0.5 \mu \mathrm{I}$ volume of cell suspension was implanted into the right dentate gyrus or into the right cerebellar hemisphere.

Controls. As a control for the possibility that ${ }^{3} \mathrm{H}-$ thymidine from transplanted cells could be taken up by the host dividing cells, freezethaw killed cells were implanted. A cell suspension of $100,000 \mathrm{cells} / \mu \mathrm{l}$ (viability, 90\%) was prepared from the cerebella of P-2 rat pups injected intraperitoneally with ${ }^{3} \mathrm{H}$-thymidine. An aliquot of the cell suspension was freeze thawed two to three times using dry ice and a $37^{\circ} \mathrm{C}$ water bath, respectively. Absence of cell viability was assayed by the trypan blue test and the (3-[4,5-dimethylthiazol-2-yl]-2,5-diphenyltetrazolium bromide) (MTT) survival assay (Mosmann, 1983). The levels of radioactivity per volume of cell suspension of living or freeze-thaw killed cells were equivalent. Transplantation and analysis of animals implanted with alive or dead cells was done in parallel.

Cell implantation. Cells were implanted into the hilar region of the dentate gyrus or into the cerebellum of neonatal rat or mouse pups following previously described methods, which allow reproducible placement of cells into discrete structures of very young animals (Renfranz et al., 1991; Cunningham and McKay, 1993; Cunninghan et al., 1993). Animals were anesthetized by placing in ice for 3-6 min. Each animal was then positioned into a miniaturized hypothermic stereotaxic instrument (Cunningham neonatal rat adaptor, Stoelting Co., Wood Dale, IL) fixed to a standard adult stereotaxic instrument. A midline in ion in the skin over the head of the animal was made and the skull sutace was cleared of tissue. At the site of the appropriate coordinates for the dentate gyrus or the cerebellum, a $1 \mathrm{~mm}$ diameter area of skull was removed using a low-speed drill equipped with a dental burr. Hippocampal implants were placed $1.7 \mathrm{~mm}$ lateral to midline, $1.2 \mathrm{~mm}$ posterior to bregma, and $2.1 \mathrm{~mm}$ below dura in P-2 rat pups or $1.4 \mathrm{~mm}$ lateral to midline, $0.8 \mathrm{~mm}$ posterior to bregma, and $1.4 \mathrm{~mm}$ below to dura in P-4 mouse pups. Cerebellar implants were placed $1 \mathrm{~mm}$ lateral to midline, $1 \mathrm{~mm}$ caudal to the parietal fissure, and $1 \mathrm{~mm}$ below dura in P-2 rat pups. Using a pulled glass pipette tip with a final o.d. of 50$70 \mu \mathrm{m}$ connected to a Hamilton syringe, $0.5 \mu \mathrm{l}$ of the cell suspension was injected over $2 \mathrm{~min}$. The pipette was left in this position for $2 \mathrm{~min}$ and then withdrawn over 3 min. The surgical area was cleaned with sterile saline, the incision was sutured, and the animal was revived on a $37^{\circ} \mathrm{C}$ heating pad and returned to its mother.

Histochemistry. One to two months after transplantation, 26 of the transplanted animals ( 21 rats and 5 mice) were injected intraperitoneally with kainic acid at $1030 \mathrm{mg} / \mathrm{kg}$ in order to induce the synthesis of FOS proteins by cells in the hippocampus (Popovici et al., 1990). Then the animals were deeply anesthetized with ethyl ether and transcardially perfused with $\mathrm{NaCl} 0.9 \%$ followed by $2-4 \%$ paraformaldehyde in phosphate buffer $\mathrm{pH}=7.4$. For lac Z histochemistry, the animals were perfused with phosphate-buffered saline (PBS) containing $2 \mathrm{mM} \mathrm{MgCl}$ followed by $2 \%$ paraformaldehyde $/ 2 \mathrm{mM} \mathrm{MgCl} / 5 \mathrm{mM}$ EGTA $0.2 \%$ $(\mathrm{v} / \mathrm{v})$ glutaraldehyde in piperazine- $\mathrm{N}, \mathrm{N}^{\prime}$-bis-[2-ethanesulfonic acid] (PIPES) $\mathrm{pH}=6.9$. Brains were postfixed for $2 \mathrm{hr}$ in the corresponding fixative at $4^{\circ} \mathrm{C}$, immersed overnight at $4^{\circ} \mathrm{C}$ in $30 \%$ sucrose, embedded in OCT, and cut in 10-20 $\mu \mathrm{m}$ cryostat sections. Sections were collected onto glass slides coated with $1 \mathrm{mg} / \mathrm{ml}$ poly-L-lysine.

Air-dried sections were permeabilized with $0.2-0.4 \%$ Triton X-100/ 5-15\% Normal Serum, and incubated overnight at room temperature with the primary antibodies against calbindin-D28kd (1:200) and NSE (1:500), or overnight at $4^{\circ} \mathrm{C}$ with the primary antibodies against $E$. coli $\beta$-galactosidase (1:500), FOS (1:2000), or GFAP (1:500). For $\beta$-galactosidase staining, sections were treated with $10 \% \mathrm{H}_{2} \mathrm{O}_{2}$ during $10 \mathrm{~min}$

Figure 4. ${ }^{3} \mathrm{H}-$ Thymidine-labeled cerebellar cells grafted into the developing dentate gyrus differentiate to express locale-specific neuronal markers. $A$, Normal calbindin staining in the dentate gyrus. Note the immunopositive granule cells $(g c)$ and their dendritic network in the molecular layer $(m)$ (inset shows a high magnification of calbindin staining in the dentate granule layer). $B$ and $C$, Transplanted cells can be identified by clusters of silver grains overlying calbindin-positive cell bodies (arrows) in thin $(10 \mu \mathrm{m})$ tissue sections. Labeled cells in $B$ are located in the granule cell layer near its border with the hilus. The cells shown in $C$ lie at the lateral tip of the suprapyramidal wing of the granule cell layer. Calbindinnegative-labeled cells are also present (arrowheads). Not all endogenous granule neurons are calbindin positive, as can be seen in the immunonegative region of the granule cell layer adjacent to the hilus in $A$. $D$, Typical immunostaining of kainate-induced FOS in granule neurons (inset shows a high magnification of FOS staining in the dentate granule layer). $E$ and $F$, Transplanted cells (arrows) in the granule cell layer upregulate FOS as seen in thin cryostat sections. FOS-negative transplanted cells (arrowheads) are usually found outside the granule cell layer, in the hilus $(H)$ or in the molecular layer $(m)$. $G$ and $H$, GFAP-positive transplanted cells can be found throughout the grafted tissue, such as the two examples (in $G$ ) in the molecular layer (arrowheads) and in the hilus $(H)$ (inset shows overlying silver grains). $I$, Cells grafted back into the cerebellum are found predominantly in the granular layer $(g)$ and are not immunoreactive for calbindin in contrast to the Purkinje cells $(p)$. Scale bars: $A$ and $D$, $100 \mu \mathrm{m} ; B, C$, and $E-I, 10 \mu \mathrm{m}$. Section thickness: $A$ and $D, 30 \mu \mathrm{m} ; B, C, E, F$, and $I, 10 \mu \mathrm{m} ; G$ and $H, 20 \mu \mathrm{m}$. These results were consistent in all transplanted animals with optimal placement of the graft. 

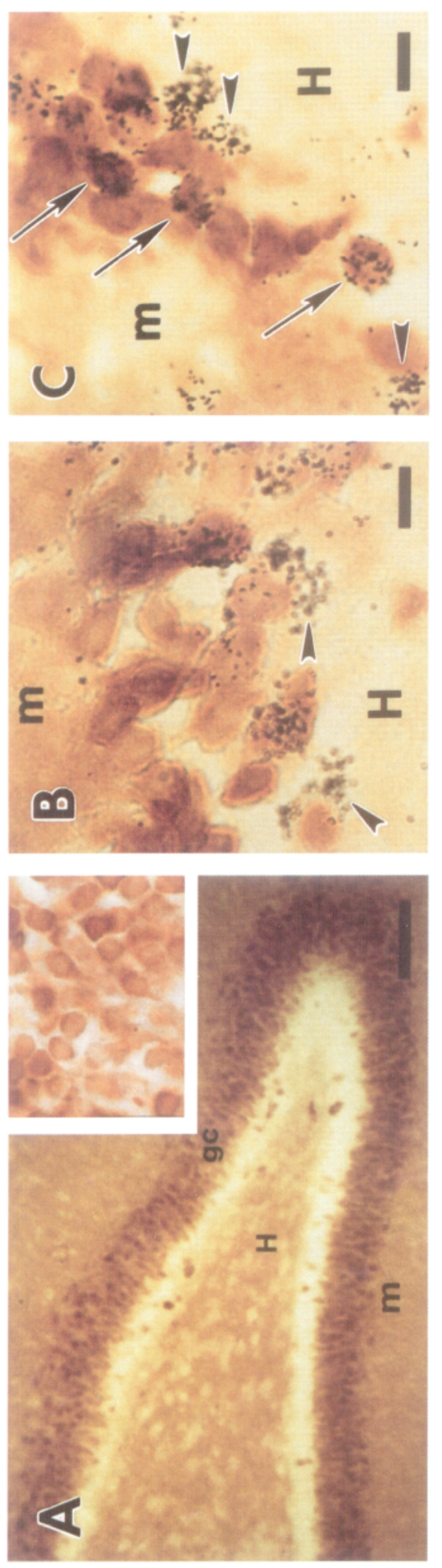

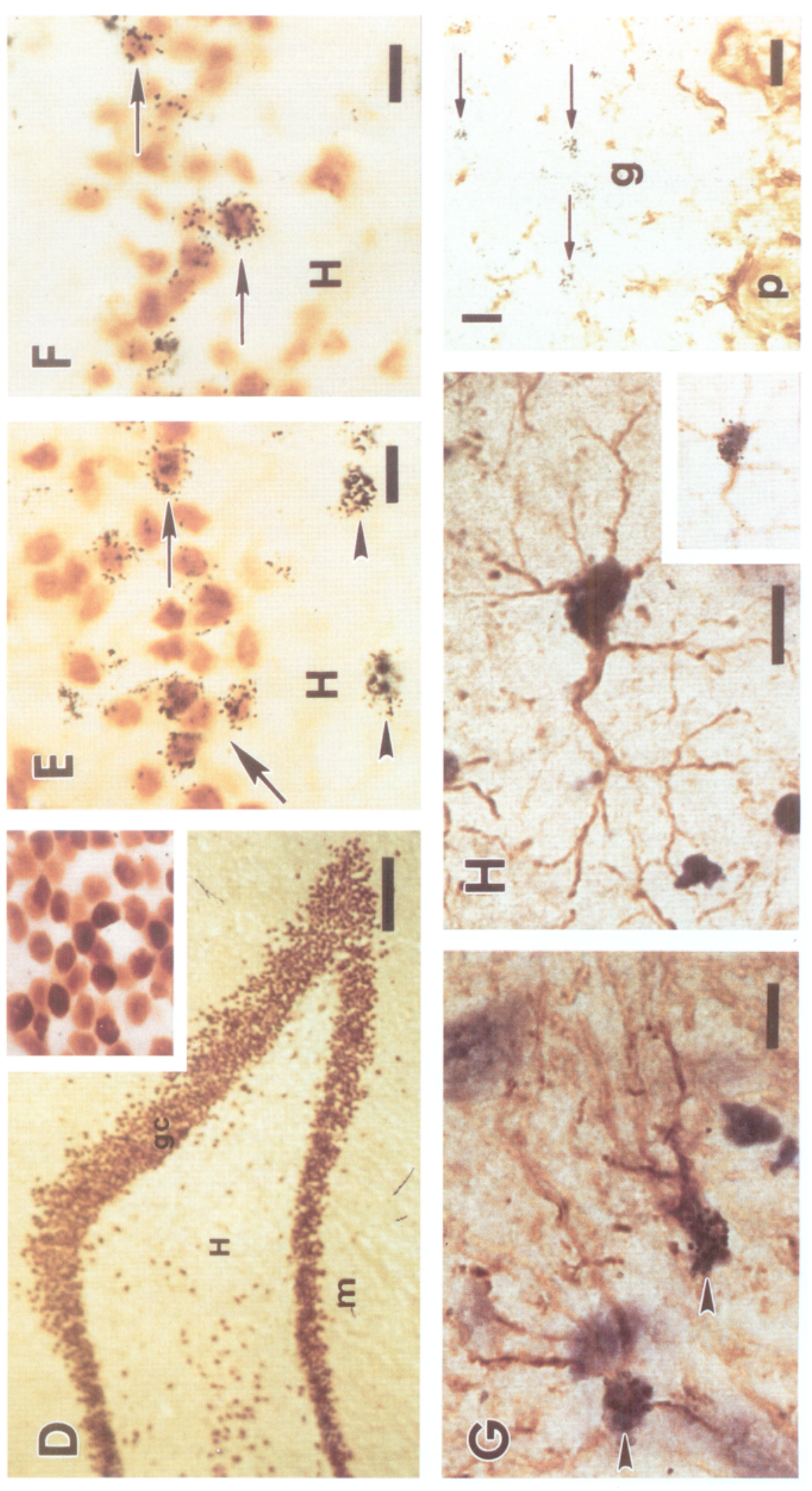


before the permeabilization/blocking step. The sections were then incubated with the corresponding biotinylated secondary antibody (1:200) followed by avidin-biotin-horseradish peroxidase complex (Vectastain $\mathrm{ABC}$ kit) and processed with $\mathrm{DAB}$ and $\mathrm{H}_{2} \mathrm{O}_{2}$. Finally, the sections were dehydrated, and coverslipped with Permount.

For lac $Z$ histochemistry a previously described method (Price and Thurlow, 1988) was followed. Air-dried sections were postfixed with $0.5 \%$ glutaraldehyde in PBS $/ 2 \mathrm{mM} \mathrm{MgCl} \mathrm{M}_{2}$ for $15 \mathrm{~min}$ at $4^{\circ} \mathrm{C}$. After two rinses with $\mathrm{PBS} / 2 \mathrm{mM} \mathrm{MgCl}_{2}$, the sections were permeabilized with detergent solution $(0.01 \%$ sodium deoxycholate, $0.02 \%$ nonidet $\mathrm{P}-40$ in $\mathrm{PBS} / 2 \mathrm{mM} \mathrm{MgCl} 2$ for $15 \mathrm{~min}$ at $4^{\circ} \mathrm{C}$. To visualize the $\beta$-galactosidase activity, the sections were incubated $6-12 \mathrm{hr}$ at $37^{\circ} \mathrm{C}$ in the detergent containing $5 \mathrm{mM} \mathrm{K}_{3} \mathrm{Fe}(\mathrm{CN})_{6}, 5 \mathrm{mM} \mathrm{K}_{4} \mathrm{Fe}(\mathrm{CN})_{6}$, and $2.5 \mathrm{~mm}$ of X-Gal.

When antibody immunostaining and lacZ histochemistry was performed on the same sections, the tissue was first incubated to visualize the $\beta$-galactosidase activity. When antibody immunostaing and autoradiography was done, the tissue was first procesed for the detection of the antigen. For developing the thymidine-[methyl- $\left.{ }^{3} \mathrm{H}\right]$, sections were defatted in ethanol and xylenes, dried, and exposed to emulsion NTB2 (Eastman Kodak) for 8-10 weeks in the presence of the desecant Drierite. Then the sections were immersed in developer D19, H2O, and rapid fixer (Eastman Kodak) for $3 \mathrm{~min}, 15 \mathrm{sec}$, and $3 \mathrm{~min}$, respectively (Rogers, 1967). Finally, sections were washed with $\mathrm{H}_{2} \mathrm{O}$, dried, dehydrated, and mounted with Permount.

Electron microscopy. For electron microscopy analysis, animals were perfused with phosphate-buffered saline containing $2 \mathrm{mM} \mathrm{MgCl}_{2}$ followed by $2 \%$ paraformaldehyde $/ 2.5 \%$ (v/v) glutaraldehyde in phosphate-buffered saline $/ 2 \mathrm{mM} \mathrm{MgCl}_{2}$. Sections $250 \mu \mathrm{m}$ thick were cut on a vibrating microtome and free-floating sections were reacted with $\mathrm{X}-\mathrm{Gal}$. Regions containing transplanted cells were microdissected in cacodylate buffer. Tissue was osmicated, dehydrated in serial ethanol grades, embedded in accelerated epon-araldite, and 60-80 nm thin sections were placed on FORMVAR-coated slot grids and stained with uranyl acetate and lead citrate. Sections were viewed and photographed on a JEOL $1200 \mathrm{CX}(80 \mathrm{kv})$ electron microscope.

\section{Results}

In the developing mouse and rat brain, the main wave of neurogenesis lasts from embryonic day 11 (E11) to E17 (Jacobson, 1991). During this period, cells such as the hippocampal pyramidal cells and the cerebellar Purkinje cells become postmitotic (Altman and Das, 1965; Altman, 1972; Schlessinger et al., 1975; Altman and Bayer, 1990). However, proliferation of precursor cells giving rise to cerebellar granule neurons, and precursors for hippocampal granulc ncurons begins at the end of the cmbryonic period and reaches a peak during the first postnatal week of life (Altman and Das, 1965; Altman, 1972; Schlessinger et al., 1975; Altman and Bayer, 1990). The cerebellum derives from the mesencephalon/metencephalon and the hippocampus from the telencephalon (Martínez and Alvarado-Mallart, 1989; Hallonet et al., 1990; Jacobson, 1991; Hallonet and Le Douarin, 1993; Hatlen and Heinlz, 1995). These facts provide developmentally equivalent donor and host sites that are phylogenetically disparate.

Cerebellar cell suspensions were made from newborn rats that had received tritiated thymidine injections and from newborn transgenic mice carrying a lac $Z$ gene driven by a neuron-specific promoter (Forss-Petter et al., 1990). Microliter volumes of cell suspensions were placed into the hilar region of the dentate gyrus using a refined stereotaxic transplantation system (Renfranz et al., 1991; Cunningham and McKay, 1993; Cunningham et al., 1993). Autoradiography for thymidine labeling and histochemical reactions ( $X-G a l$, anti- $\beta$-galactosidase antibody) for the presence of the $l a c Z$ gene were used to identify transplanted cells.

\section{Identifying transplanted cells}

Identification of ${ }^{3} \mathrm{H}$-thymidine-labeled transplanted cells was achieved by comparing the number of silver grains overlying cell nuclei in tissue grafted with living versus freeze-thaw killed ${ }^{3} \mathrm{H}$-thymidine-labeled cerebellar cells (see Fig. 1). A low level of labeling was present with dead cell grafts, no single cell having more than 15 silver grains. This labeling may represent the nonspecific transfer of thymidine from the grafts to host cells. Only cells with more than 20 silver grains were scored positively as transplanted cerebellum-derived cells (Fig. $2 A$ ). This criterion is supported by the fact that most cerebellar precursor cells were found to have more than 20 grains when postnatal day $2(\mathrm{P}-2)$ rat pups were injected with thymidine and sacrified $4 \mathrm{hr}$ after the last dose (data not shown).

With this approach, the number of surviving transplanted cells was estimated using the formula of $\Lambda$ bercrombie ( $\Lambda$ bercrombie, 1946): $P=A[M /(M+L)]$, where $P$ is the corrected number of cells per section, $A$ is the uncorrected number of cells per section, $\mathrm{M}$ is the section thickness, and $\mathrm{L}$ is the average diameter of a cell in a section. Figure $2 B$ illustrates the numbers and distribution of positively scored cells in the dentate gyrus from two serially sectioned animals. Approximately 912 cells could be found in the granule cell layer, 270 in the molecular layer, and 150 in the hilar region of the dentate gyrus. These values show that $70 \%, 20 \%$, and $10 \%$ of cells survived in each region, respectively. The total number of grafted cells was 50,000; approximately $2 \%$ of grafted cells were integrated in the granule cell layer. Note that since the radioactivity of poorly labeled grafted cells or progeny of grafted cells is diminished, they would not be scored as positive. It is therefore probable that this method underestimates the numbers of recovered cells. Additional (uncounted) cells were seen elsewhere, in the hippocampal fissure, the third and lateral ventricles.

LacZ-labeled cells from transgenic animals were measured in a similar manner, as shown in Figure $2 C$. In one animal, 435 cells were found in the granule cell layer; $70 \%$ of the surviving cells were found in the dentate gyrus. This number represents $1 \%$ of grafted cells. Significantly, many X-Gal-positive cells survived and expressed the lac $Z$ gene in the dentatc granule layer for at least 6 months and the intensity of $l a c Z$ expression was found to increase with the age of the transplanted animal. The discrepancy between the numbers of ${ }^{3} \mathrm{H}$-thymidine-labeled cells and the numbers of transgenic cells may be accounted for by variable levels of expression of the NSE-lacZ gene.

The distribution of transplanted cerebellar cells located in the dorsal and ventral blades, and in the crest of the granule cell layer can be seen in Figures 1 and 5. A detailed analysis of this distribution of ${ }^{3} \mathrm{H}$-thymidine-positive cells and $\mathrm{X}$-Gal-positive cells is given in Figure 3, in which each blade and crest of the granule cell layer has been divided into three shells. This representation allows comparison of the position of the transplanted cells with the gradients of formation of the granule cell layer (Schlessinger et al., 1975; Altman and Bayer, 1990). More than $90 \%$ of the cells are found in the dorsal or ventral blades, and $5-7 \%$ in the crest. $56 \%$ of X-Gal-positive cells and $65 \%$ of ${ }^{3} \mathrm{H}-$ thymidine-positive cells are located in the intermediate shell. Fewer cells are found in the outer or inner shells. This location of the grafted cells correlates with the pattern of migration of host granule cell precursors present at the time of transplantation (Schlessinger et al., 1975; Altman and Bayer, 1990).

\section{Differentiation of transplanted cells}

The differentiation of the transplanted cells was assessed using morphological criteria on the light and electron microscopic level and by the expression of cell-type specific proteins. The cal- 
cium binding protein, calbindin, is expressed by dentate gyrus granule neurons (Fig. 4A) (Baimbridge and Miller, 1982; Sloviter, 1989). FOS is also strongly expressed by dentate gyrus granule neurons during seizure aclivity produced by kainic acid, an agonist of glutamate receptors (Fig. 4D) (Popovici et al., 1990). FOS induction was used to determine whether this shortterm change in gene expression was the same in transplanted and host neurons. Cerebellar granule neurons express neither FOS in response to kainic acid treatment (Fig. $5 H$, inset) nor do they express calbindin (Figs. 4I, 5H). Thus, the expression of calbindin and FOS was used to indicate the region-specific differentiation of the transplanted cerebellar granule cells.

$\Lambda$ s seen in Figure $4 I$ and $5 H$, cerebellar Purkinje cells are calbindin positive and express FOS upon kainic acid treatment (Fig. 5H, inset) or $\alpha$-amino-3-hydroxy-5-methyl-4-isoxazolepropionate (AMPA) (Nakazawa et al., 1993). However, since they are already postmitotic, Purkinje cells do not become labeled when P-2 pups are injected with thymidine. Furthermore, Purkinje cells are rarely found when cerebellar suspensions were transplanted back into the cerebellum (Figs. 4I, 5II) (see Discussion). Glial fibrillary acidic protein (GFAP) was used as a criterion for astrocytic differentiation.

Tritiated thymidine-labeled transplanted cells integrated into the granule cell layer where their cell bodies and nuclei were indistinguishable from the surrounding host cells. A large proportion of these cells $(70 \%)$ were found to express calbindin (Fig. 4B,C). Many intensely radiolabeleld cells in the granule cell layer (85\%) also strongly expressed FOS as a consequence of seizure activity (Fig. $4 E, F$ ); transplanted cells were FOS negative when seizures were not elicited. Labeled cells located outside the granule cell layer were invariably devoid of calbindin and FOS immunostaining (Fig. 4B,E). Smaller numbers of cells were seen in the hilar region and the molecular layer of the dentate gyrus. Many of these cells (40\%) could be identified as positive for GFAP (Fig. 4G,H). When the cells were grafted back into the cerebcllum, they integrated predominantly into the granular layer. Like host cerebellar granule cells, the engrafted cells did not express calbindin (Fig. $4 I$ ); however, grafted cells robustly expressed NSE (see Fig. 5h). Few of the cells grafted to the cerebellum expressed the astrocytic marker GFAP (data not shown).
The long-term expression of a transgene after engraftment is a useful alternative method for identifying implanted cells. Transplantation of cells derived from NSE-lac $Z$ mice was also used to characterize the differentiated state of cerebellar cells in the dentate gyrus. The expression of the NSE-lac Z transgene by cells is neuron specific and pan neuronal (Forss-Petter et al., 1990). After transplantation from the cerebellum, NSE-lacZ neurons were identified in the dentate gyrus (Fig. 5), particularly in the granule cell layer. The morphological features of the lacZpositive engrafted cells and endogenous neurons of the dentate gyrus appeared to be identical (Fig. 5A-G). Similar conclusions were derived by using anti- $\beta$-galactosidase antibodies to identify grafted cells (Fig. 6). Most of the engrafted cells assumed the same size and shape as dentate gyrus granule neurons (oval, with a diameter of 7-10 $\mu \mathrm{m}$ in the rat) (Figs. $5 A, B, D, F, G, 6$ ). Figure $5 E$ illustrates a grafted cell with the morphology of a displaced granule neuron, first described by Ramón y Cajal (Ramón y Cajal, 1984): the laterally elongated cell body is displaced slightly from the granule cell layer with processes extending out into the molecular layer. Much less frequently, cells were identified with features similar to pyramidal basket neurons, having larger cell bodies and being positioned at the border of the dentate granule layer and the hilar region (Ribak and Anderson, 1980) (Fig. 5C).

When the X-Gal reaction was combined with immunohistochemistry, engrafted cells located in the granule cell layer were shown to express calbindin (Fig. $5 D, E$ ). Furthermore, during seizure activity, FOS is strongly expressed by transplanted cells (Fig. $5 F, G$ ). In contrast, cells implanted back into the cerebellum are negative for calbindin (Fig. $5 H$ ) and positive for NSE (Fig. $5 I$ ). As can be seen when comparing Figure $5 A$ with Figures $5 H$ and $I$, more surviving cells were found when cerebellar cells were transplanted homotopically into the cerebellum than when transplanted heterotopically into the dentate gyrus. Thus, the results from transgenic transplantation experiments recapitulate and strengthen the data obtained with radiolabcled grafted cclls. This analysis suggests that cerebellar cells respond to the signals that organize the cytoarchitecture of the dentate gyrus.

To further assess the differentiated state of transplanted cerebellar cells, the electron-dense X-Gal reaction product was utilized to obtain ultrastructural information. The dense reaction

Figure 5 (left). Transplanted transgenic cerebellar cells that express the NSE-lacZ transgene integrate into the host dentate gyrus, assume neuronal morphologies, and express neuron-specific antigens. $A$, Low-power view of X-Gal-reacted grafted dentate gyrus. Transplanted cells produce a dense blue reaction product and are seen distributed in the granule cell layer $(g c)$. X-Gal-labeled cells are seen in the hilus $(H)$ and the molecular layer $(m)$ less frequently. $B$ and $C$, High-power view of engrafted cells (arrows) in the granule cell layer demonstrating a typical hippocampal granule cell morphology $(B)$ and a less common pyramidal basket neuron morphology $(C) . D$ and $E$, Calbindin immunostaining reveals transplanted cells (arrows) residing in the granule cell layer that express this locale-specific neuronal marker. The cells in $D$ were located at the apex of the granule cell layer at its border with the molecular layer. The cells in $E$ were photographed at the very tip of the suprapyramidal wing of the granule cell layer. Since the numbers of granule neurons taper in this region, details of the morphology of grafted cells could more easily be appreciated in this neuron-sparse area. Note the displaced granule neuron features of the larger labeled cell shown in $E$. Transplanted cells can also be identified as calbindin negative (arrowheads in $E$ ). Transgenic cells lying outside the granule cell layer were negative for calbindin. $F$ and $G$, Transgenic cerebellar cells in the granule cell layer (arrows) upregulate FOS upon challenge with kainic acid. The strongly double-labelled cell (arrow) in $G$ is located in the neuron-sparse internal border of the apex of the granule cell layer near the hilar region. H, Transgenic cells (arrows) grafted into the rat cerebellum populate the granular layer $(g)$ and are not immunoreactive for calbindin in contrast to the Purkinje cells $(p)($ inset shows FOS immunoreactivity in Purkinje but not in granule neurons in response to kainic acid). $I$, Transgenic cells (arrows) grafted into the rat cerebellum strongly express NSE. Scale bar: $A, 100 \mu \mathrm{m} ; B-I, 10 \mu \mathrm{m}$. Section thickness: $A-D$ and $F, 20 \mu \mathrm{m} ; E$ and $G-I, 10 \mu \mathrm{m}$. These results were consistent in all transplanted animals with optimal placement of the graft.

Figure 6 (right). Antibodies against $E$. coli $\beta$-galactosidase confirm that the morphology of cerebellar transplanted cells is similar to that of host granule neurons. Note that the shape (oval) and size (7-10 $\mu \mathrm{m}$ cell body diameter) of the $\beta$-galactosidase-positive cells found in the hippocampal dentate granule cell layer is identical to that of host granule neurons. The cell in $A$ was located in the tip of the ventral blade of the granule cell layer. The cell in $B$ was located in the crest of the granule cell layer. After DAB reaction and Nissl staining, cells were visualized and photographed at $1000 \times$. The magnification used for photographic enlargement was $1.8 \times$. Scale bar, $5 \mu \mathrm{m}$. Section thickness, $20 \mu \mathrm{m}$. The results were obtained from the analysis of two grafted animals. 

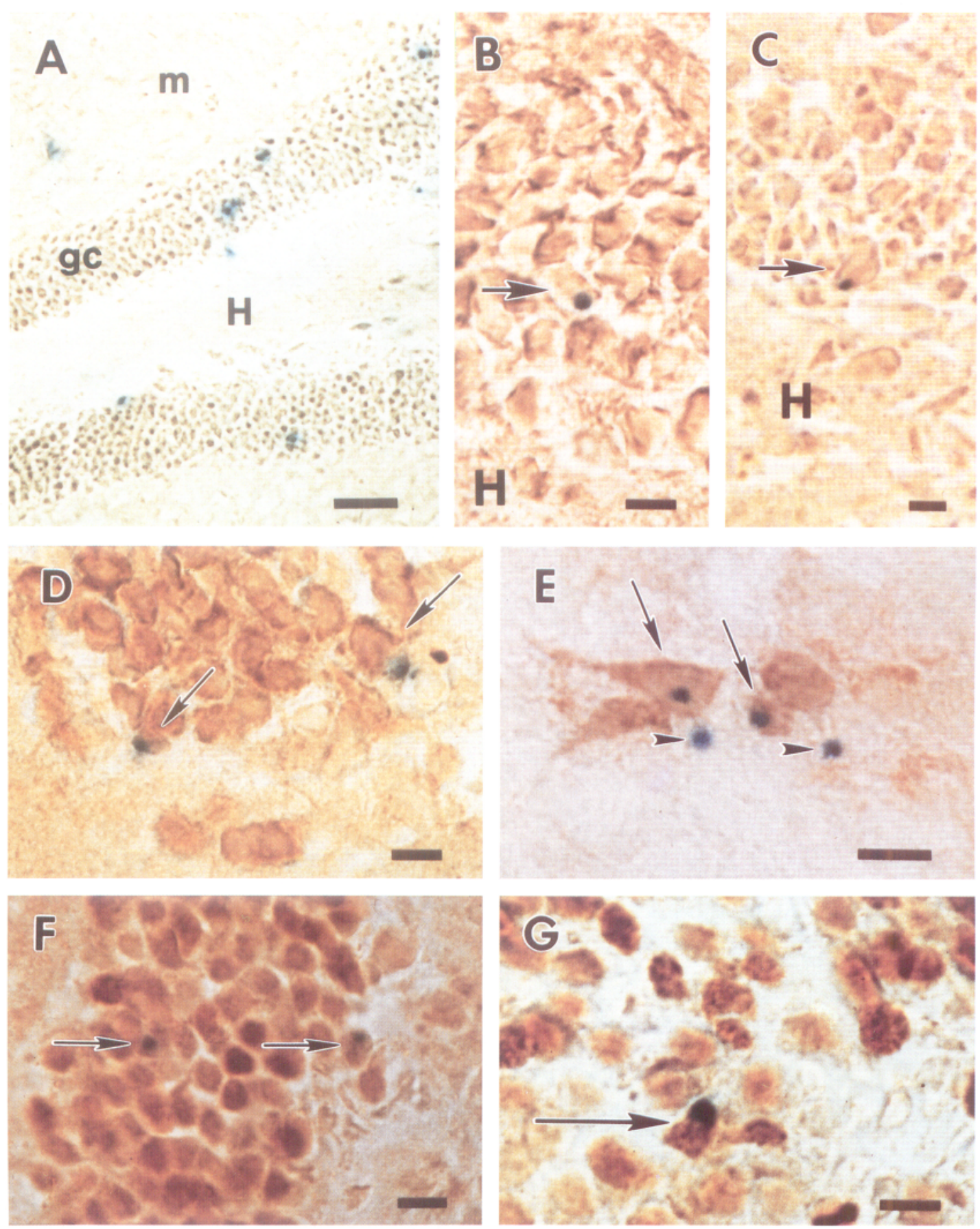

H. 9 o olo b d $x^{9} 1$ 2 (p) 1. $0.2 \times 1$

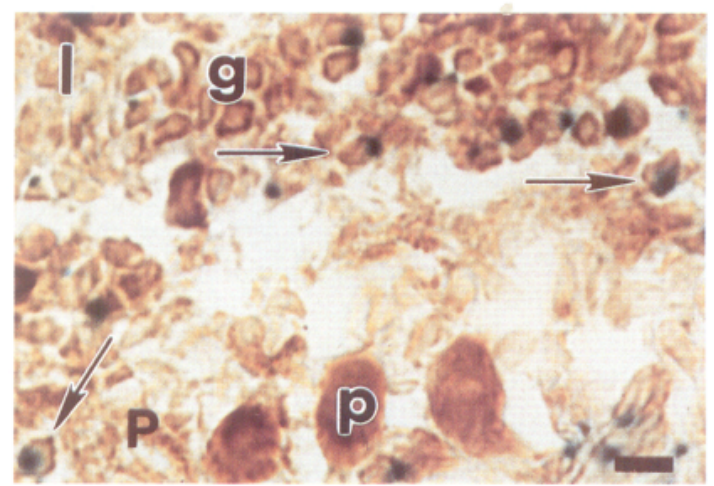




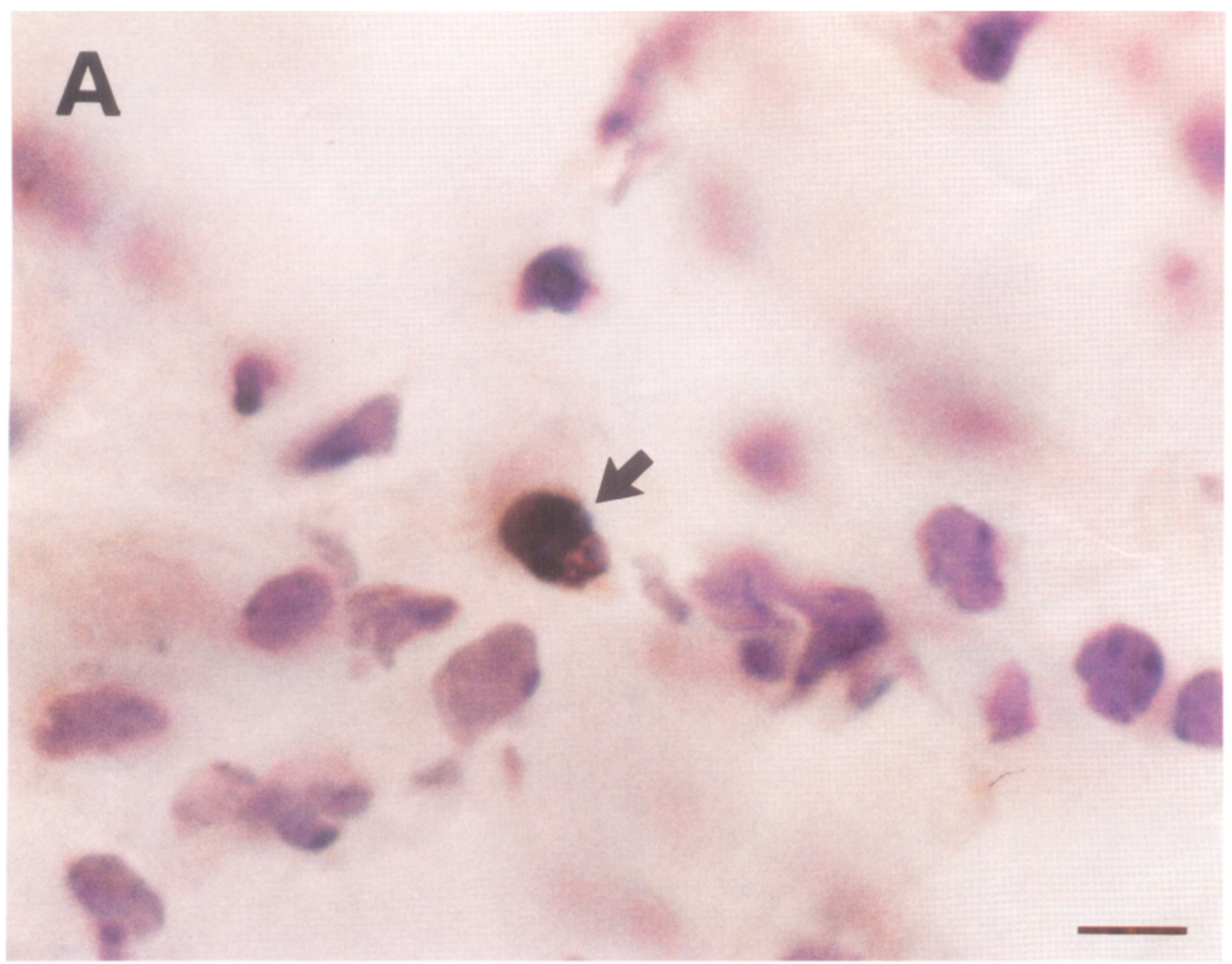

B

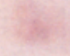

4

- 
product is seen associated with the nuclear membrane, endoplasmic reticulum, and other organelles (Fig. $7 D$, inset). It should be noted that the exposure of the tissue to the X-Gal detergent solutions disiupts the integrity of cell membranes and diminishes the resolution of ultrastructural features.

Rat hippocampal granule neurons are $7-10 \mu \mathrm{m}$ in diameter with a nuclear envelope that is rarely indented. They have less hetero-chromatin than cerebellar granule neurons, an eccentric nucleolus and have little cytoplasm (see Fig. 7B) (Laatsch and Cowan, 1966). In contrast, cerebellar granule neurons (see Fig. 7A) are smaller, 5-6 $\mu \mathrm{m}$ diameter, and have cytoplasmic indentations in the nucleus. The nucleus of the cerebellar granule neuron is also characterized by large masses of condensed chromatin arranged around the inner wall of the nuclear envelope in a clock-face manner (Palay and Chan-Palay, 1974).

Cells with electron-dense crystallization product in the dentate gyrus were the same size as host hippocampal granule neurons; they did not show the nuclear indentations or the chromatin condensation pattern characteristic of cerebellar granule neurons (Fig. $7 D, E, F$ ). The rare cell that did not show features of the dentate granule neuron (Fig. $7 G$ ) possessed an infolded nuclear envelope characteristic of dentate gyrus local circuit neurons, such as the cell shown in Fig. 7C. However, nuclear clefting has also been described in cerebellar basket or stellate cells. These EM studies suggest that the nuclear structure and soma size of transplanted cells have changed to adopt ultrastructural features of dentate granule neurons.

\section{Discussion}

The division of the CNS into distinct regions is a feature of neuronal organization with important functional consequences. Tissue transplantation has led to the view that regional specification is an early process in neurulation (Jacobson, 1964; Alvarado-Mallart and Sotelo, 1982; Kromer et al., 1983; Guthrie et al., 1992). This view has been challenged by recent transplants in chick embryos (Alvarado-Mallart et al., 1990; Nakamura, 1990; Martínez et al., 1991) and transplantation of immortalized and primary rat precursor cells (Renfranz et al., 1991; Fishell, 1995) showing grafted precursor cells giving rise to neurons appropriate to an ectopic transplant site. The experiments reported in this work show that cells in the developing postnatal cerebellum are capable of differentiating into neurons with hippocampal features. They extend previous data in several ways. First, transplantation between the mes/metencephalon and the telencephalon involves two phylogenetically distinct brain regions. Second, the use of physical and genetic labels to follow the transplanted cells permits confident quantitative analysis of the efficiency of grafting. Third, the differentiated state of the transplanted cells was assessed by immunohistochemistry for patterns of gene expression as well as light and electron microscopic morphological analysis.

Grafted animals possessed significant numbers of thymidinelabeled and lacZ-labeled cells predominantly in the granule cell layer of the dentate gyrus (Figs. $1,2 B, C, 4,5$ ). The two celllabeling techniques differ in that the thymidine is mainly incorporated into dividing precursors to cerebellar granule neurons. Purkinje, Golgi, and Lugaro cells became postmitotic before E-16 or E-17 in the mouse and rat brain (Miale and Sidman, 1961; Altman and Das, 1965). The dividing cells giving rise to other cerebellar cell types (i.e., glia, stellate, and basket cells) comprise a very small proportion of cerebellar cells at the developmental age at which tritiated thymidine was administered
(Palay and Chan-Palay, 1974; Hallonet et al., 1990; Hallonet and Le Douarin, 1993). In agreement with this, when postnatal day 2 pups (P-2) were injected with thymidine, most of the labeling was found in the granule layer. Fewer labeled cells were present in the molecular layer, and the Purkinje cells did not show thymidine labeling (data not shown). These facts show that ${ }^{3} \mathrm{H}$ thymidine-labeled cerebellar cell suspensions are mainly composed of granule neuron precursors.

In contrast, cells grafted from the transgenic mice could be derived from any neuron or neuronal precursor cell type found in the donor tissue including the Purkinje cells. In agreement with the radiolabeled data, the overwhelming majority of lacZlabeled cells transplanted back into the cerebellum integrate robustly into the granular layer and possess morphologies identical to cerebellar granule neurons (Fig. $5 H, I$ ). The similarity between the results obtained with the two labeling methods in heterotopic as well as homotopic grafts strongly suggests that the precursors for cerebellar granule neurons are acquiring features of dentate granule neurons upon transplantation. However, transplantation of purified granule and Purkinje cells would be necessary to strengthen this conclusion. Additionally, transplantation in embryonic recipients will determine whether cerebellar precursor cells can acquire features of the other major type of hippocampal neuron, the pyramidal cell.

Two factors may account for the differences in the number of grafted cells identified in the cerebellum and the dentate gyrus (compare Fig. $5 A$ vs $5 H$ and $I$ ). When transplanted in the dentate gyrus, cerebellar cells are challenged to differentiate in an ectopic environment. This raises the possibility that only a subpopulation of cerebellar granule precursors might have the ability to survive and integrate in the dentate gyrus. Alternatively, the number of cells present in a given brain region could limit the survival of transplanted cells. The adult rat dentate gyrus contains aproximately $6 \times 10^{5}$ granule cells (Schlessinger et al., 1975 ) and the adult rat cerebellum more than $10 \times 10^{6}$ (Palay and Chan-Palay, 1974). The higher absolute number of transplanted cells found in the cerebellum versus the dentate gyrus may simply be a consequence of the larger size of the cerebellum.

The distribution of the transplanted cells in the different shells of the dentate granule layer correlates well with the pattern of migration of dentate granule precursors (Fig. 3) (Schlessinger et al., 1975; Altman and Bayer, 1990). Cerebellar cells were transplanted into P-2 rats or P-4 mice, an age in which most of the cells of the outer shell, i.e., adjacent to the molecular layer, are already formed. Cells in the inner shell, i.e. adjacent to the hilar region, are mainly generated after postnatal day 7 (Schlessinger et al., 1975; Altman and Bayer, 1990). In agreement with this, only $14-17 \%$, and $19-22 \%$ of surviving cells in the granule layer are found in the outer shell or in the inner shell, respectively, of both blades. Both methods of labeling the cells, ${ }^{3} \mathrm{H}$ thymidine and $l a c Z$, indicate that most of the transplanted surviving cells migrate to the intermediate shell of the granule cell layer. In contrast to the ${ }^{3} \mathrm{H}$-thymidine label, which would be diluted by cell division, the lac $Z$ label would follow all the progeny of implanted cells. The close similarity in the numbers and distribution of grafted cells with both labels suggest that implanted cells do not undergo extensive replication. Our results suggest that the transplanted cells differentiate with the same spatial and temporal pattern of the host hippocampal dentate granule neurons.

The combination of the morphological and ultrastructural 

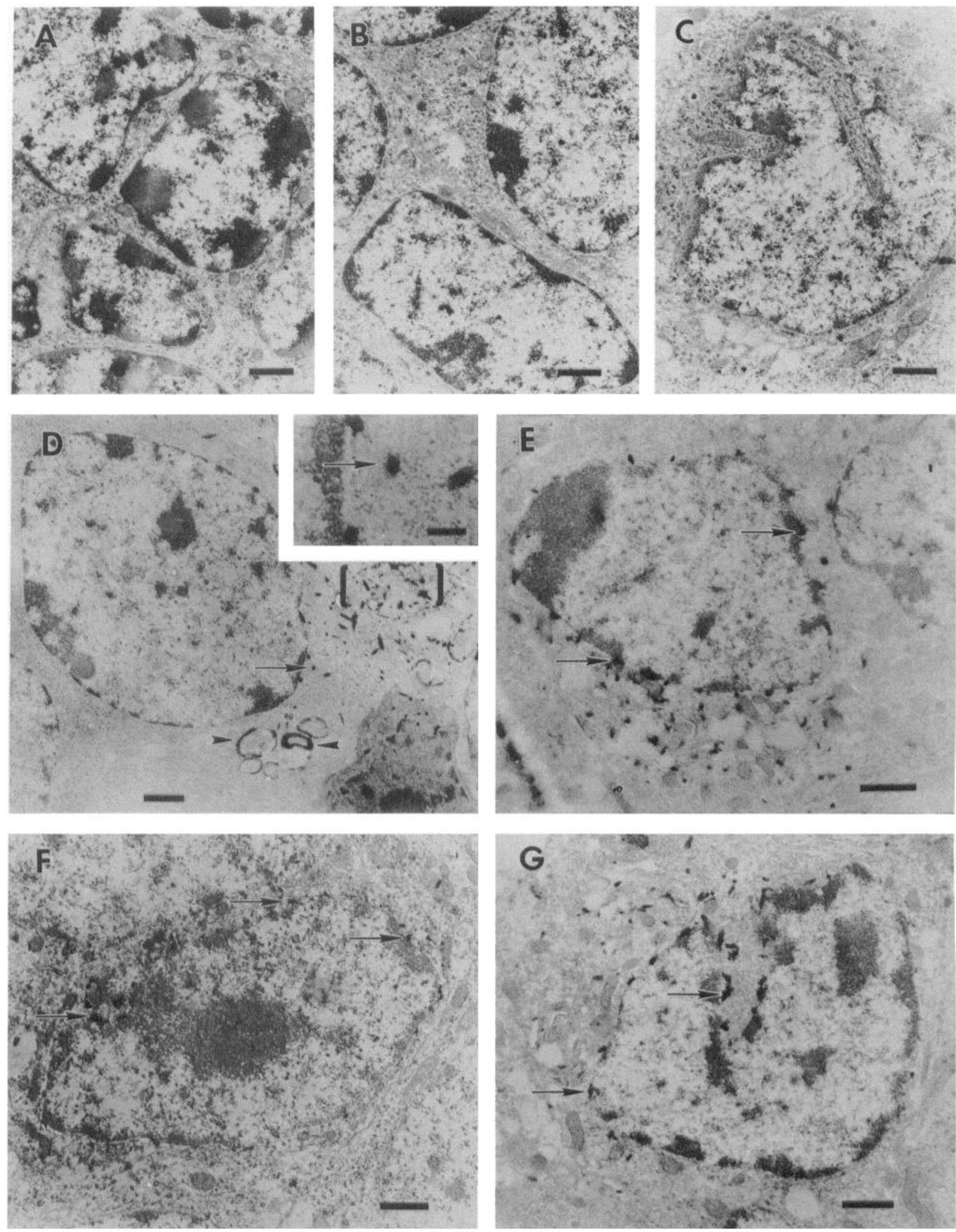

Figure 7. Ultrastructural features of transplanted cells are characteristic of endogenous dentate gyrus granule and local circuit neurons. $A, B$, and $C$, Electron micrographs of typical cerebellar granule neurons, dentate gyrus granule neurons, and a dentate gyrus local circuit neuron in situ, respectively. $D-G$, Engrafted cells in the dentate granule cell layer are identified by their electron dense, crystalline X-Gal precipitate, which is typically associated with the nuclear membrane and subcellular organelles, such as the endoplasmic reticulum $(D$, inset $) . D-F$, Transplanted cells have integrated intimately within the host tissue, showing ultrastructural features of granule cells and appear to interact normally as indicated by their close cell-to-cell contact and other features, such as myelinated fibers coursing nearby (arrowheads, $D$ ). A process of another transplanted cell (brackets) can be seen associated with the cell shown in $D$. G illustrates a transplanted cell with an infolded nuclear envelope and dispersed chromatin characteristic of local circuit neurons. Scale bars, $1 \mu \mathrm{m}$. Inset scale bar, $200 \mathrm{~nm}$. Results were obtained from the analysis of three grafted animals. 
data, the expression of the NSE-lacZ gene, the expression of calbindin, and the induction of FOS suggest that cerebellar cells have differentiated to express features that are shared with hippocampal neurons. The histological data show that transplanted cell bodies are mainly located in the hippocampal granule cell layer and have the same morphology and size as dentate gyrus neurons, as they are 40-60\% larger than cerebellar granule neurons and three times smaller than Purkinje cells (Figs. $4 A-F, 5$, 6). Electron microscopy reveals that the ultrastructural features are characteristic of cells native to the dentate gyrus rather than the cerebellum (Fig. 7). The immunohistochemistry shows that cells transplanted to the hippocampus become calbindin- (Figs. $4 B, C, 5 D, E$ ) or FOS-positive (Figs. $4 E, F, 5 F, G$ ), but are negative when transplanted to the cerebellum (Figs. $4 I, 5 H$ ). Furthermore, the FOS data show that expression of this immediate early gene by grafted cells is induced similarly as in hippocampal granule neurons. These results suggest that hippocampal signals can recruit cerebellar precursors to differentiate into dentate granule neurons.

A number of studies have shown that c-fos is transcribed by neurons in response to trans-synaptic activity (Dragunow and Robertson, 1987; Sheng and Greenberg, 1990). Cerebellar granule neurons are known to upregulate FOS in response to 1-methyl-4-phenyl-1,2,3,6-tetrahydropyridine (MPTP) treatment (Duchemin et al., 1992), electroconvulsive shock (Duval et al., 1989), and ischemia (Wessel et al., 1991). Purkinje cells in the adult cerebellum express FOS in response to kainic acid (Fig. $5 H$, inset) and $\alpha$-amino-3-hydroxy-5-methyl-4-isoxazole-propionate (AMPA) (Nakazawa et al., 1993); however, the size and morphology of transplanted cells expressing FOS in the dentate granule cell layer is similar to host granule cells (Figs. $4 E, F$, $5 F, G$ ). Although FOS can be induced in astrocytes (Hisanaga et al., 1992; Ladenheim et al., 1993; Onteniente et al., 1994), we did not observe FOS upregulation in astrocytes after kainic acid treatment (data not shown). Moreover, the FOS-positive transplanted cells found in the dentate granule cell layer express neuronal markers and have a neuronal morphology. In the present studies, most transplanted cells in the granule cell layer expressed FOS, while nearby transplanted cells in the hilus or molecular layer were FOS negative. This specificity is the same as is seen for host neurons where FOS is most rapidly induced in the cells of the granule cell layer of the dentate gyrus. Thus, in addition to their morphological similarities, the transplanted cells induce FOS in a similar way to hippocampal granule neurons, suggesting that host and implanted cells are responding to the same inductive stimuli.

Our results suggest that extracellular signals can determine the fate of the precursors for cerebellar granule neurons at the time of neurogenesis. Previous work reported that the granule neurons are the only type of cerebellar cells originating in the EGL (Hallonet et al., 1990; Hallonet and Le Douarin, 1993). No change in fate was seen when intact embryonic cerebellum or reaggregated cerebellar cells where transplanted into several sites in the adult brain, including the hippocampus (AlvaradoMallart and Sotelo, 1982; Wells and McAllister, 1982; Kromer et al., 1983; Ezerman and Kromer, 1985). Homotopic grafts of primary EGL precursors into the developing cerebellum gave rise only to granule neurons (Gao and Hatten, 1994). These studies suggested that EGL progenitor cells are commited to a cerebellar granule cell phenotype early in neurogenesis. However, as we show, when these precursors are placed in a heterotopic region, they are able to shift their fate and express characteristics of the host site.

The present results are consistent with our previous observations that an immortal hippocampal precursor cell differentiates into neurons in a regionally appropriate manner (Renfranz et al., 1991). Similarly, recent work has shown that striatal progenitor cells adopt cortical fates when transplanted into the cortical ventricular zone (Fishell, 1995). The transplantation of primary and immortal neuronal precursors between the hippocampus and the cerebellum supports the conclusion that region-specific neuronal differentiation may be established by extracellular signals acting on neuronal precursor cells at the time of neurogenesis.

\section{References}

Abercrombie M (1946) Estimation of nuclear populations from vibratome sections. Anat Rec 94:239-247.

Altman J (1972) Postnatal development of the cerebellar cortex in the rat. III. Maturation of the components of the granular layer. J Comp Neurol 145:465-514.

Altman J, Bayer S (1990) Migration and distribution of two populations of hippocampal granule cell precursors during the perinatal and postnatal periods. J Comp Neurol 301:365-381.

Altman J, Das G (1965) Autoradiographic and histological evidence of postnatal hippocampal neurogenesis in rats. J Comp Neurol 124: 319-336.

Alvarado-Mallart R, Sotelo C (1982) Differentiation of cerebellar anlage heterotopically transplanted to adult rat brain: a light and electron microscopy study. J Comp Neurol 212:247-267.

Alvarado-Mallart R, Martínez S, Lance-Jones C (1990) Pluripotentiality of the 2 day-old avian germinative neuroephitelium. Dev Biol 139:75-88.

Baimbridge K, Miller J (1982) Immunohistochemical localization of calcium-binding protein in the cerebellum, hippocampal formation and olfactory bulb of the rat. Brain Res 245:223-229.

Barbe M, Levitt P (1991) The early commitment of fetal neurons to the limbic cortex. J Neurosci 11:519-533.

Cunningham M, McKay R (1993) A hypothermic miniaturized stereotaxic instrument for surgery in newborns rats. J Neurosci Methods 47:105-114.

Cunningham M, Nikkhah G, McKay R (1993) Grafting immortalized hippocampal cells into the brain of the adult and the newborn rat. Neuroprotocols: A companion to methods in neurosciences. 3:260272.

Dragunow M, Robertson H (1987) Kindling stimulation induces c-fos protein(s) in granule cells of rat dentate gyrus. Nature 329:441-442.

Duchemin A, Gudehithlu K, Feff N, Hadjiconstantinou M (1992) c-fos mRNA in mouse brain after MPTP tratment. Neurochem Int 20:281 287.

Duval J, Nakajima T, Gleiter C, Post R, Marangos P (1989) Mouse brain c-fos mRNA distribution following a single electroconvulsive shock. J Neurochem 52:1954-1957.

Ezerman E, Kromer L (1985) Development and neuronal organization of dissociated and reaggregated embryonic cerebellum after intracephalic transplantation to adult rodent recipient. Dev Brain Res 23: 287-292.

Fishell G (1995) Striatal precursors adopt cortical identities in response to local cues. Development 121:803-812.

Forss-Petter S, Danielson P, Catsicas S, Battenberg S, Price J, Nerenberg M, Sutcliffe J (1990) Transgenic mice expressing $\boldsymbol{\beta}$-galactosidase in mature neurons under neuron-specific enolase promoter control. Neuron 5:187-197.

Gao W, Hatten M (1994) Immortalization oncogenes subvert the establishment of granule cell identity in developing cerebellum. Development 120:1059-1070.

Gray G, Glover J, Majors J, Sanes J (1988) Radial arrangement of clonally related cells in the chicken optic tectum: lineage analysis with a recombinant retrovirus. Proc Natl Acad Sci USA 85:73567360 .

Gruss P, Walther C (1992) Pax in development. Cell 69:719-722.

Guthrie S, Muchamore I, Kuroiwa A, Marshall H, Krumlauf R, Lums- 
den A (1992) Neuroectodermal autonomy of Hox-2.9 expression revealed by rhombomere transpositions. Nature 356:157-159.

Hallonet M, Le Douarin N (1993) Tracing neuroepithelial cells of the mesencephalic and metencephalic alar plates during cerebellar ontogeny in quail-chick chimaeras. Eur J Neurosci 5:1145-1155.

Hallonet M, Teillet M, Le Douarin N (1990) A new approach to the development of the cerebellum provided by the quail-chick marker system. Development 108:19-31.

Hatten ME, Heintz N (1995) Mechanisms of neural patterning and specification in the developing cerebellum. Annu Rev Neurosci 18: $385-408$.

Hisanaga K, Sagar S, Sharp F (1992) C-fos induction occurs in cultured cortical naurons and astrocytes via multiple signaling pathways. Prog Brain Res 94:189-195.

Holt C, Bertsch T, Ellis H, Harris W (1988) Cellular determination in the Xenopus retina is independent of lineage and birthdate. Neuron 1:15-26.

Jacobson C (1964) J Embryol Exp Morphol 7:1-21.

Jacobson M (1991) Developmental neurobiology. New York: Plenum.

Kromer L, Bjorklund A, Stenevi U (1983) Intracephalic embrionic neural implants in the adult rat brain. I. Growth and mature organization of brainstem, cerebellar, and hippocampal implants. J Comp Neurol 218:433-459.

Krumlauf R (1993) Hox genes and pattern formation in the branchial region of the vertebrate head. TIG 9:106-112.

Laatsch R, Cowan W (1966) Electron microscopic studies of the dentate gyrus. J Comp Neurol 128:359-396.

Ladenheim R, Lacroix I, Foignant-Chaverot N, Strosberg A, Couraud $P$ (1993) Endothelins stimulate c-fos and nerve growth factor expression in astrocytes and astrocytoma. J Neurochem 60:260-266.

Luskin M, Parnavelas J, Barfield J (1993) Neurons, astrocytes, and oligodendrocytes of the rat cerebral cortex originate from separate progenitor cells: an ultrastructural analysis of clonally related cells. $\mathbf{J}$ Neurosci 13:1730-1750.

Martínez S, Alvarado-Mallart R (1989) Rostral cerebellum originates from the caudal portion of the so-called "mesencephalic" vesicule: a study using chick/quail chimeras. Eur J Neurosci 1:549-560.

Martinez S, Wassef A, Alvarado-Mallart R (1991) Induction of mesencephalic phenotype in the 2-day-old chick prosencephalon is preceded by the early expression of the homeobox gene en. Neuron 6:971-981.

McConnell S (1988) Fates of visual cortical neurons in the ferret after isochronic and heterochronic transplantation. J Neurosci 8:945-974.

McConnell S (1991) The generation of neuronal diversity in the central nervous system. Annu Rev Neurosci 14:269-300.

McConnell SK, Kaznowski CE (1991) Cell cycle dependence of laminar determination in developing neocortex. Science 254:282-285.

McMahon A, Bradley A (1990) The Wnt-1 (int-1) proto-oncogene is required for development of a large region of the mouse brain. Cell 62:1073-1085.

Miale I, Sidman R (1961) An autoradiographic analysis of histogenesis in the mouse cerebellum. Exp Neurol 4:277-296.

Mione M, Danevic C, Boardman P, Harris B, Parnavelas J (1994) Lineage analysis reveals neurotransmitter (GABA or Glutamate) but not calcium-binding protein homogeneity in clonally related cortical neurons. J Neurosci 14:107-123.

Mosmann T (1983) Rapid colorimetric assay for cellular growth and survival: application to proliferation and cytotoxicity assays. J Immunol Methods 65:55-63.
Nakamura H (1990) Do CNS anlage have plasticity in differentiation. Analysis in quail-chick chimcra. Brain Res 511:122-128.

Nakazawa K, Karachot L, Nakabeppu Y, Yamamori T (1993) The conjunctive stimuli that cause long-term desensitization also predominantly induce c-Fos and Jun-B in cerebellar Purkinje cells. Neuroreport 4:1275-1278.

Onteniente B, Horellou P, Neveu I, Makeh I, Suzuki F, Bourdet C, Grimber G, Colin P, Brachet P, Mallet J, Briand P, Peschanski M (1994) Cell-type-specific expression and regulation of a c-fos-NGF fusion gene in neurons and astrocytes of transgenic mice. Brain Res Mol Brain Res 21:225-234.

Palay S, Chan-Palay V (1974) Cerebellar cortex. Cytology and organization. New York: Springer.

Popovici T, Represa A, Crépel V, Barbin G, Beaudoin M, Ben-Ari Y (1990) Effects of kainic acid-induced seizures and ischemia on c-foslike proteins in rat brain. Brain Res 536:183-194.

Price J, Thurlow L (1988) Cell lineage in the rat cerebral cortex: a study using retroviral-mediated gene transfer. Development 104:473482.

Puelles L, Rubenstein J (1993) Expression patterns of homeobox and other putative regulatory genes in the embryonic mouse forebrain suggest a neuromeric organization. Trends Neurosci 16:472-479.

Ramón y Cajal S (1984) Les nouvelles idées sur la structure du system nerveux chez l'homme et chez les vertebrés. Paris: Reinwald \& Cie.

Renfranz PJ, Cunningham MG, McKay RDG (1991) Region-specific differentiation of the hippocampal stem cell line HiB5 upon transplantation into the developing mammalian brain. Cell 66:713-729.

Ribak C, Anderson L (1980) Ultrastructure of the pyramidal basket cells in the dentate gyrus of the rat. J Comp Neurol 192:903-916.

Rogers A (1967) Techniques of autoradiography. London: Elsevier.

Rubenstein JLR, Martínez S, Shimamura K, Puelles L (1994) The embryonic vertebrate forebrain: the prosomeric model. Science 266 : $578-580$.

Schlessinger A, Cowan W, Gottlieb D (1975) An autoradiographic study of the time of origin and the pattern of granule cell migration in the dentate gyrus of the rat. J Comp Neurol 159:149-176.

Sheng M, Greenberg M (1990) The regulation and function of c-fos and other immediate early genes in the nervous system. Neuron $4: 477-485$.

Simeone A, Gulisano M, Acampora D, Stornaiuolo A, Rambaldi M, Boncinelli E (1992) Two vertebrates homeobox genes related to the Drosophila empty spiracles gene are expressed in the embryonic cerebral cortex. EMBO J 11:2541-2550.

Sloviter RS (1989) Calcium-binding protein (calbindin-D28k) and parvoalbumin immunocytochemistry: localization in the rat hippocampus with specific reference to the selective vulnerability of hippocampal neurons to seizure activity. J Comp Neurol 280:183-196.

Snyder EY, Deitcher DL, Walsh C, Arnold-Aldea S, Hartwieg EA, Cepko CL (1992) Multipotent neural cell lines can engraft and participate in development of mouse cerebellum. Cell 68:33-51.

Turner DL, Cepko CL (1987) A common progenitor for neurons and glia persists in rat retina late in development. Nature 328:131-136.

Wells J, McAllister I (1982) The development of cerebellar primordia transplanted to the neocortex of the rat. Dev Brain Res 4:167-179.

Wessel T, Joh T, Volpe B (1991) In situ hybridization analysis of c-fos and c-jun expression in the rat brain following transient forebrain ischemia. Brain Res 567:231-240.

Wetts R, Fraser SE (1988) Multipotent precursors can give rise to all major cell types of the frog retina. Science 239:1142-1145.

Yamada T, Placzek M, Tanaka H, Dodd J, Jessell M (1991) Control of cell pattern in the developing nervous system: polarizing activity of the floor plate and notochord. Cell 64:635-647. 